\title{
Research on Practical Teaching System Of Applied Accounting Major
}

\author{
Zhifeng Jie
}

School of Accounting, Nanchang Institute of Science \& Technology, Nanchang, Jiangxi, China

\author{
Key words: Accounting, PracticeTeaching, System
}

\begin{abstract}
According to the present situation of practical application of accounting major teaching, the cultivation of innovative talents as the goal of applied financial and meeting the market demand for financial talent as a starting point, it should establish the construction of professional disciplines in the "integration" and "cultivating stage" level "and" teaching mode of multi-channel "practice teaching system to achieve the application type accounting major teaching practice teaching reform.
\end{abstract}

\section{Introduction}

As market demand for financial talent, accounting major should change the past, focus on theory teaching practice situation and be guided by the market in the construction of professional disciplines "integration" and "cultivating stage" level "and" teaching mode channel of the practical teaching system.

\section{Related literature Review}

For the study of the practice teaching system of applied accounting major study abroad, in the beginning of 1960s, such as Rebecca S and Bill Redding in the Lorwyn "creating the cold war University: the transformation of Stanford University" a Book of modern university which has been transformed into a "managed by the business giant" and "knowledge giants". "Legal entity" as the research starting point, mainly concentrated in the curriculum teaching form, the diversity of teaching plan, practice time is more abundant and the diversity of the base construction of the main aspects for the practice of accounting major teaching form development applies to the practice of theoretical research and practice to promote the mutual development of circulation.

From the domestic such as ideal and reality, theory and practice, knowledge and action of three basic dimensions (Wang Jianhua, 2011), which promote the transformation and development of university new subject reform (Liu Fahu and Zhang Yantong, 2011) and other point of view, pointed out in the national development mode from Europe and the United States with a corresponding teaching system based on the practice of accounting major students (Wang Jianfei and Zhao Zhe, 2013).It combined with the actual situation of the domestic application of accounting major, the professional personnel training objectives. They dealt with the relationship between theory and practice teaching, implement the teaching contents, form and practice base.

\section{Current Situation Of Practical Teaching Of Applied Accounting Major}

(I).The content of practice teaching is slow and systematic

In practice, the old teaching content, courses and textbook of accounting major is similar and no more new content innovation and reform, not with the practice and professional development update.

The practice of the basic course of the specialty is too much and repetitive in the aspect of the 
practical teaching content, which is concluded that the single training is too much, the content is repeated and the cohesion is not strong.

(II). Teaching resources and the lack of double qualified teachers

It is difficult to guarantee the quality of practical teaching for the practical teaching resources of applied accounting. First, due to the restriction of traditional management concept, the lack of teaching resources and overall deployment of effective, which cannot be shared and solve students' existing scale to the practice of curriculum on learning operation opportunities for small, formal teaching and assessment of simple problems. Second, the teaching related software is the same as uneven financial, comprehensive practice of accounting software. The software function is different from the teaching content of colleges and universities in the choice of financial software and makes the operation more than from the teaching level but from a cost perspective, which resulted in the teaching of financial software can't meet the needs of teaching.

Third, the accounting professional practice teaching with other resources is not perfect, such as information, cyber source inside and outside the deployment and use of teaching and practice teaching materials and so on ,which are not fully taken into account the relevant curriculum characteristics and benefits.

There are teaching process and knowledge structure in the application of accounting major practice Teaching "double type" teachers. In the process of teaching, professional theory and practice teachers are usually different, who are separated from some college practice teaching center and professional theory teaching units which makes students learn the knowledge of the curriculum theory in practical courses during the operation.

In the aspect of knowledge structure, there are a lot of teachers who lack practical experience and lack of scientific research. As a result, it is difficult for the teachers with rich theoretical knowledge to teach the latest knowledge in the teaching process. Finally, students can't use the new knowledge to solve the practical problems in the practical courses.

(III)Backward teaching mode

The practical teaching mode of applied accounting major is summarized as follows: first of all, students learn the professional knowledge to prepare and form corresponding materials for the practice content of e practice teachers.

Second, practice teachers of teaching students in accordance with the requirements carry out the operation, in accordance with the principles of teacher practice, steps and related matters.

Finally, teachers and students explain the final review of the formation of learning materials or reports.

The above teaching mode of training students in accordance with fixed thinking operation, not too much independent thinking.

Therefore, it is not possible to stimulate students' interest in learning practical courses and difficult to cultivate applied financial talents with the ability to analyze, solve problems and innovative thinking.

\section{Construction Of Practical Teaching System Of Applied Accounting Major}

To achieve training objectives and meet market demand for applied financial talents, application-oriented undergraduate accounting major should construct "integration" and "cultivating stage" level "and" teaching mode of multi-channel "practice teaching system to achieve effective teaching practice reform in view of the current practice teaching content and mode of the present situation in the field of discipline.

(I)Discipline integration 
Accounting major course puts forward the idea of "integration" in view of the deficiency of practical teaching content of applied. Specifically, it should be implemented around the training applied accounting major talents from the discipline system of strategy. At the same time, it should consider professional practice course layout and settings in the overall design of system of professional theory and professional courses.

(II)Stage of culture

It is necessary to form a "hierarchy" under the premise of "integration" in the discipline of applied accounting major course.

In practice teaching, it based on students' cognitive ability, training stage "hierarchical" embodies "the foundation to improve and innovation" to make the students practical ability to improve solid foundation stage operation stage, proficient, explore innovative design stage".

(III)Teaching methods "multi-channel"

In order to solve the shortage of practical teaching resources of applied accounting major course, colleges and universities take the "multi-channel" teaching method on the difference of teaching content and the link of the undergraduate course.

With the aim of cultivating applied financial talents, we should develop the network teaching resources, introduce the open practice teaching method, construct the theory to guide the teaching process, and establish a new type of teacher-student relationship. The main open practice room is not open practice In the basic stage. At the same time, the training room and practice is open in the stage of improvement and innovation. In the course of practice teaching, we should change the traditional teaching mode and guide students to construct their own knowledge system by means of questioning. In addition, the effective use of online resources which are supplemented by multimedia courseware for network teaching is the establishment of virtual training room on the internetto achieve diversification of teaching methods.

It is important to realize the resource sharing and information operation by optimizing the practice resource management. It is to ensure the open practice teaching by changing the traditional training room division concept, establishing a fundamental teaching practice as the basic platform, comprehensive practice of open, realize the sharing of resources and information operations, to build a comprehensive and professional design practice teaching platform.

It is important to strong then the construction of teaching staff. First, construction of teaching staff is according to the "double quality" requirements.

The "double teacher" team building can adopt the theory teachers who must participate in the practice of teaching and research work, meanwhile, practice class teachers are trained to improve the theoretical level and scientific research ability, two-way culture to accelerate "double teacher" team building. Second, it is urgent to improve the quality of teachers, especially young and middle-aged teachers, because they are backbone of practical teaching. Experienced teachers should have the spirit of dedication. And then young teachers should learn something from experienced teachers modestly. In addition, reasonable arrangements for all teachers have the opportunity to study. It requires all teachers to carry out teaching, research, "two gang" rotation system in order to improve teachers' basic teaching ability, humanities, social Sciences, psychological quality and professional ethics.

\section{Conclusion}

At present, there are still many problems in the teaching contents, resources, models, teachers and evaluation system of the practical teaching of applied accounting. The existence of these problems prompted professional training objectives and met needs of $t$ market for financial talent 
needs to be improved. These measures include the construction of "integration, multi-level, multi-channel" practical teaching model, enriching the "double teacher" teachers and the establishment of part-time and practical teaching team. It also provides more content for further study in the following aspects: the cultivation of talents training plan, the practice teaching system and the optimization of curriculum structure.

\section{Acknowledgment}

Fund Project: Project supported by Nanchang Institute of Science \& Technology in 2016 (NGJG-16-65).

\section{References}

[1]Shaodongwei.Reflections on the teaching of undergraduate accounting courses [J],China Securities Futures,2010,(12):116-118.

[2]Jin ying.Discussion on the teaching methods of accounting course in Colleges and Universities [J],Shijiazhuang Journal,2011,(9):20-124.

[3] Sun jingqun, Zhu wenshuang.Construction and implementation of innovative practical teaching system of Accounting Specialty [J],Friends of accounting,2010,(12):114-115.

[4] $\mathrm{Xu}$ ronghua,Lin bo.Research on accounting practice teaching in Independent Colleges[J],Enterprise Herald,2011,(10):110.

[5] Yang chengyan.Design and implementation of integrated accounting experiment project [J],Finance \& Accounting for Communications,2014,(7):51-57.

[6] Yao huayun.Discussion on the practice teaching system of Accounting Specialty [J],Accounting of township enterprises in China,2010,(2):169-170.

[7] Wang wei.The present situation and Countermeasures of accounting professional training mode in Private Colleges [J],Education Forum,2015,(1):78-81.

[8]David K. Eiteman, Arthur I. Stonehill, Michael H. Moffett, Multinational Business Finance ninth edition Addison-Wesley Publishing Company, Inc. 2001. 